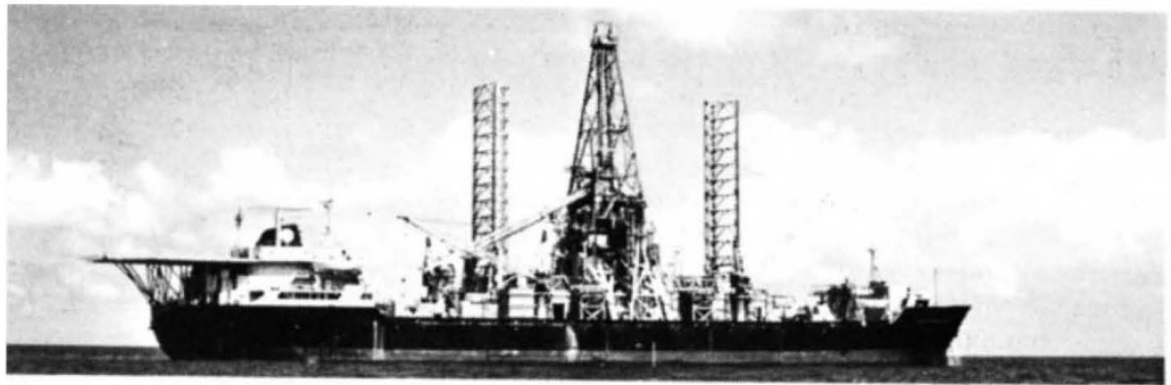

Glomar Explorer: bound for seabed surveying?

\title{
Congress puts NSF deep sea drilling project in doubt
}

THE US House of Representatives, citing concern at the balance between 'big science' and 'little science' projects within the programme of the National Science Foundation, has rejected the foundation's proposals for a major start in a deep sea drilling project which is expected to cost between $\$ 450$ million and $\$ 550$ million over the next ten years.

In its budget proposals for 1979, the NSF wanted to spend $\$ 4.2$ million on design and feasibility studies for a major drilling programme to explore the geophysics of the continental margin. The project would include the conversion into a geophysical survey ship of the Glomar Explorer, originally built by the Howard Hughes Corporation for the Central Intelligence Agency at a cost of more than $\$ 200$ million, but used only once in an attempt to recover a Soviet submarine from the floor of the Pacific.

In its debate last week on authorisation of the NSF's budget for 1979, however, the House of Representatives accepted the recommendation of its Science and Technology Committee, under the chairmanship of $\mathrm{Mr}$ Olin Teague, that only $\$ 1$ million be authorised for expenditure on the project in 1979. In making this suggestion, the committee said that, although it was not opposed to the drilling project as such, it felt that the case had not been adequately made for including the full expenditure of the $\$ 4.2$ million in the 1979 budget. An amendment offered by Congressman Breaux of Louisiana which would have restored the extra $\$ 3.2$ million was rejected by the House by 291 votes to 111 .

The committee's recommendation was made in the light of its concern about the relative balance of 'big science' and 'little science' in the NSF's programmes. It suggested the NSF should establish a formal procedure for deciding the priority of different 'big science' proposals before undertaking further large expenditure on any new ones.
The committee said the NSF's request for $\$ 4.2$ million for starting the deep sea drilling project "contained no indication that the total cost of the programme was estimated at $\$ 450$ million over 10 years", and there was no discussion of alternative big science projects which might also need support, such as the "next large telescope". It also suggests that Congress should consider requiring the foundation to request specific authorisation for each new 'big science' project, as is currently done by the National Aeronautics and Space Administration (NASA).

The total NSF authorisation for 1979 recommended by the committee and accepted by the House by 364 votes to 37 , is $\$ 934.4$ million, almost exactly the figure requested by President Carter. This figure represents an increase of about $8 \%$ over this year's budget. Within this overall figure, the authorisation for science education has been increased from $\$ 77.6$ million to $\$ 82$ million, the committee claiming that it had, as in previous years, been disappointed by the low level of the NSF's request.

To compensate for this, the committee says that, while it applauds the president's decision to strengthen support for basic science in 1979, it "reluctantly" recommends a slight decrease in the amount requested by the NSF for basic research. Included in this category is a $\$ 3.2$ million decrease in funds authorised for mathematical and physical sciences and engineering.

Unlike previous years, the NSF's budget proposals have so far gone relatively smoothly through Congress. A resolution to reduce spending on social science research, a stumbling block in the past, was rejected by the House by 174 votes to 229 . And in the Senate, Senator Kennedy's health and scientific research subcommittee of the human resources committee last week authorised the NSF's request virtually unchanged.

David Dickson
Lister Institute closes vaccine laboratories

THE Lister Institute of Preventive Medicine announced its plans to close its vaccine and sera laboratories at Elstree last week. The laboratories manufacture most of the diphtheria, tetanus and whooping cough vaccine used in the UK and are the only UK manufacturers of gas-gangrene serum and smallpox vaccine.

The reason for the laboratories closure is purely financial, according to their director, Professor L. $\mathbf{H}$. Collier. The Lister Institute has always funded research from the income earned from its manufacturing activities. Until 1970 this was sufficient to maintain two research units, the one attached to Elstree and a laboratory devoted entirely to research at Chelsea. In addition, the Institute runs the Blood Products Laboratory, also at Elstree, which is wholly financed by the Department of Health and Social Security (DHSS).

Financial difficulty started during the period of high inflation in the early 1970 s. In spite of the fact that the vaccine and sera laboratories stepped up their production of vaccines and antitoxins from 12.4 million to 25.4 million does per year in four years, profits were still not large enough to pay for the research effort. Because the Institute felt that it could only be successful with a successful research programme, in 1975 it decided to close its Chelsea laboratories and concentrate on Elstree.

The plan had been to sell the Chelsea property and to use the proceeds to refurbish facilities and continue funding research at Elstree. After a year on the market, however, the building was not sold. In 1976, the Institute applied to the DHSS for a grant of $£ \frac{1}{2}$ million to keep its Elstree research facilities running. Last year the grant was refused and the Institute subsequently decided to close the vaccine and sera laboratories.

Production is expected to stop within a few months. But according to Professor Collier it will be the middle of next year before existing stock is despatched and the laboratories can be finally closed. As an economy measure research at Elstree has been reduced since 1974. Since the Lister Institute was established in 1891 it has contributed to many advances in preventive medicine. It produced the first diphtheria antitoxin used in the UK, developed freeze-dried smallpox vaccine, widely used throughout the world, and worked on the transmission of plague, sleeping sickness and trachoma. Recently, however, research has concentrated on rabies and tetanus. Of the 105 employees at the vaccine 
and sera laboratories, less than ten are engaged in research work.

The DHSS is confident that any gap in the UK and export demand for vaccines can be supplied by the other two UK manufacturers, Wellcome and a subsidiary of Glaxo. It was decided not to grant $£ \frac{1}{2}$ million to the Lister Institute because it was reluctant to finance a commercial undertaking, especially when there were other competitive manufacturers, and because it felt that more than $£ \frac{1}{2}$ million would be needed to fund the Institute's plans.

When the Chelsea property and the vaccine and sera laboratories are finally sold the Institute plans on using the proceeds to further research into immunology. Just how it will do that will not be known until it knows how much money will be available.

Judy Redfearn

\section{Scientists prepare for UNCSTD}

Ат a meeting called by the International Council of Scientific Unions (ICSU) in Paris last January, a steering committee was set up to consider what the non-governmental organisations (NGOs) in science and technology can contribute to the United Nations Conference on Science and Technology for Development (UNCSTD) which is to be held in Vienna next August. The committee has already started organising a symposium which will probably be the most important preliminary to UNCSTD so far as the world scientific community is concerned. It is scheduled for January 1979 and will be held in a developing country-possibly Singapore-where the 70 or so scientists and others being invited will meet for six working days.

The steering committee is chaired by Dr T. F. Malone, director of the Holcomb Institute, Butler University, and convened by Maurice Goldsmith, director of the Science Policy Foundation, London. Little difficulty is anticipated in financing the symposium.

ICSU emphasises that the objective of the steering committee is not to involve scientists directly in the proceeding of UNCSTD, which is now accepted as essentially a political conference, although it is hoped that wherever possible, scientists will be included in national delegations. The aim is also to see what can be done to continue whatever comes out of the conference that is of concern to the scientific community. Put in somewhat pompous officialese, it is "to explore institutional and other innovations which would enlarge and enhance opportunities for scientists and engineers to participate in future years in the contributions of science and tech- nology to the improvement of the human condition". The stress is on continuing activity, and this is in line with the ideas of such other nongovernmental organisations as the Pugwash Conference, the World Federation of Engineering Organisations (WFEO), and the International Social Science Council (ISSC) involved on the outer perimeter of the conference preparations.

Pugwash has already had several meetings in developing countries to examine, amongst other things, the political, economic and even (where the multinational corporations are concerned) psychological problems that may arise for scientists when the conclusions of UNCSTD come to be applied in developing countries. The evolution of guidelines for study at the frontiers of science-especially in agriculture and energy - and the relationship between disarmament and development are other fields being examined by this group in the UNCSTD context.

For ISSC, things are somewhat different. It is felt that the social sciences should have been involved from the first, but in fact it was only at the recent Geneva meeting of the UNCSTD preparatory committee that ISSC appeared as an observer. ISSC feels that its members are only asked to help when the economists and technologists find that their theories are not being accepted or put into practice in the developing countries. Even the UN Development Programme excluded anything like sociology from its projects until recently: now that the fact is being appreciated that development deals with people, as well as economics and industry, the situation is changing. Certainly the experience of the social scientists will be needed if science and technology are to be usefully applied in the developing world.

Peter Collins

\section{Hungary happy with its science}

Hungarian science, like that of all Comecon countries, is channelled towards the needs of production. The expansion of $R$ \& $D$ needed for the "scientific-technological revolution" in the Hungarian economy made a somewhat slow start, so that in 1964-1969 only $78-82 \%$ of the direct nonrepayable government grants for $R$ \& $D$ were being taken up by the bodies concerned.

A recent report from the Central Committee of the Hungarian Socialist Workers' Party and the Academy of Sciences gives a more promising picture, however. This notes, approvingly, that the "over-all science policy has met the test in practice"

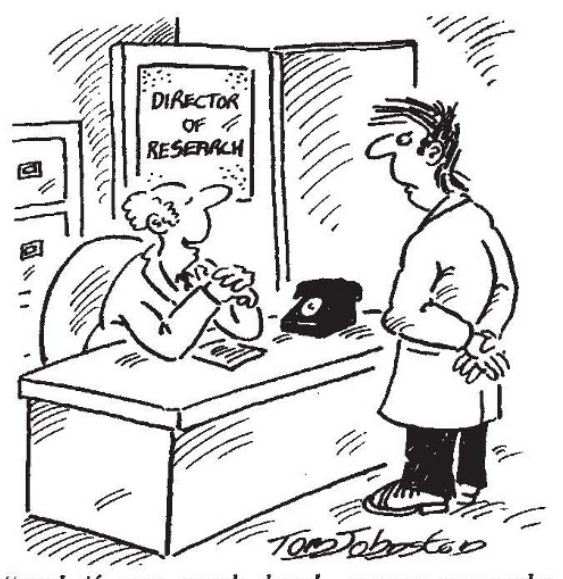

"and if you work hard, young comrade, you may one day get a key to the creators' washroom!"

(which, in Socialist terminology, refers first and foremost to the practice of the factory floor). Some $3.5 \%$ of the national income is now being spent on scientific research, while more than 80,000 persons are employed at the various research bases throughout the country.

This expansion, although gratifying to those who compile statistics of national achievements, is apparently causing some problems in practice. A recent broadcast on Budapest radio noted that as Hungarian science is now in a state of transition from "individual sovereignty" to "the necessity of project guidance", the number of scientific personnel is "statistically upsetting".

If the era of classical scientists has now gone by, it asked, is there any justification for the old concessions of flexible working hours, free days and sabbaticals to be granted in the name of "creative freedom"? At present, anyone with a diploma, who works in a research institute, is granted the "status of a scientist"- - even if he is only doing routine work, and is "someone who over several years has not produced any evidence; someone who has been searching, but discovered nothing". Why, it is asked, should the "privileges granted to creators" be extended to the "noncreative masses of specialists"?

The basic problem, said the speaker, is organisation. The ideal organiser should not be a stickler for "dictatorial project leadership" but should be someone able to "harmonise scientific objectives with the aspirations of researchers; a person who demands qualitative results, who is not merely of the managerial class, but a scientist who can win the respect of individualistic researchers". Preliminary research has shown that some scientists were disturbed and others stimulated by time-limits imposed on their creative thinking-a "diversity of individuality" which the wise project director would do well to respect.

Vera Rich 